\title{
PENGARUH CUSTOMER VALUE, PERSEPSI KUALITAS DAN KEPERCAYAAN TERHADAP RETENSI PELANGGAN (STUDI KASUS PENGGUNA SEPEDA MOTOR HONDA PADA CV INDAH SAKTI RANTAUPRAPAT)
}

\author{
Dedek Deny Lestari ${ }^{1}$, Hayanuddin Safri ${ }^{2}$ \\ ${ }^{1}$ Alumni Sarjana Ekonomi STIE Labuhanbatu \\ ${ }^{2}$ Dosen STIE Labuhanbatu
}

\begin{abstract}
ABSTRAK
Perkembangan industri otomotif sepeda motor di Indonesia setiap tahun kian meningkat sehingga menyebabkan terjadinya persaingan yang tinggi diantara para industri tersebut, ditambah lagi semakin banyak para investor dari dalam dan luar negeri menanamkan modalnya di Indonesia untuk membangun bisnis sejenis di Indonesia. Penelitian ini bertujuan untuk mengetahui pengaruh customer value secara parsial terhadap retensi pelanggan pada CV Indah Sakti Rantauprapat. Untuk mengetahui pengaruh persepsi kualitas secara parsial terhadap retensi pelanggan pada CV Indah Sakti Rantauprapat. Untuk mengetahui pengaruh kepercayaan secara parsial terhadap retensi pelanggan pada CV Indah Sakti Rantauprapat. Untuk mengetahui pengaruh customer value, persepsi kualitas dan kepercayaan secara serempak terhadap retensi pelanggan pada CV Indah Sakti Rantauprapat. Penelitian ini dilakukan CV Indah Sakti Rantauprapat Jumlah pelanggan yang terdaftar pada CV Indah Sakti Rantauprapat yang datang untuk service sepeda motor selama tahun 2015 berjumlah 3251 orang. Penarikan sampel menggunakan rumus slovin sehingga menjadi 97 sampel. Teknik pengambilan sampel pada penelitian ini dengan sampel aksidental. Teknik pengumpulan data dilakukan dengan kuesioner atau data sekunder. Teknik analisis data menggunakan analisis regresi linier berganda dengan software SPSS. Hasil penelitian menunjukkan hipotesis pertama yang diajukan dalam penelitian terbukti diterima, yang menyatakan bahwa variabel customer value memiliki pengaruh paling dominan terhadap retensi pelanggan. Hipotesis kedua yang diajukan dalam penelitian ini terbukti ditolak, yang menyatakan bahwa variabel persepsi kualitas tidak memiliki pengaruh terhadap retensi pelanggan. Hipotesis ketiga yang diajukan dalam penelitian ini terbukti diterima, yang menyatakan bahwa variabel kepercayaan memiliki pengaruh terhadap retensi pelanggan. Hipotesis keempat yang diajukan dalam penelitian ini terbukti diterima, yang menyatakan bahwa variabel customer value, persepsi kualitas dan kepercayaan secara bersama-sama memiliki pengaruh terhadap retensi pelanggan.
\end{abstract}

Kata Kunci : Customer Value, Persepsi Kualitas, Kepercayaan, Retensi Pelanggan

\section{PENDAHULUAN}

\section{Latar Belakang Masalah}

Perkembangan industri otomotif sepeda motor di Indonesia setiap tahun kian meningkat sehingga menyebabkan terjadinya persaingan yang tinggi diantara para industri tersebut, ditambah lagi semakin banyak para investor dari dalam dan luar negeri menanamkan modalnya di Indonesia untuk membangun bisnis sejenis di Indonesia. Perusahaanperusahaan tersebut selanjutnya mengembangkan konsep dan metode pemasaran yang berorientasi pada 
kebertahanan pelanggan dalam mengkonsumsi produk. Perusahaan diharapkan mampu memenuhi tuntutan pelanggan dengan pelayanan yang lebih baik dan memuaskan serta dapat menyediakan barang atau jasa yang sesuai dengan kebutuhan dan keinginan para pelanggan.

Salah satu jenis industri di Indonesia yang menjadikan pelanggan sebagai lumbung untuk memperoleh keuntungan adalah industri sepeda motor, industri sepeda motor menawarkan banyak pilihan produk yang tersedia sehingga membuat pelanggan lebih cenderung menjatuhkan pilihan sesuai dengan penilaian atau persepsi pelanggan terhadap beberapa merek sepeda motor yang menjadi favoritnya. Penilaian pelanggan atas suatu produk tersebut menjadi dasar pertimbangan perusahaan untuk berlomba-lomba memperluas pangsa pasarnya dan mencoba menarik pelanggan dengan cara mempengaruhi sikap pelanggan agar bersedia membeli produk-produk perusahaan.

Sepeda motor merupakan salah satu alternatif bepergian dari satu tempat ke tempat yang lain secara mudah, irit, cepat, luwes, efisien, dan lain sebagainya. Bagi masyarakat yang berpenghasilan rendah, motor menjadi harapan satusatunya untuk dapat memiliki alat transportasi darat pribadi sesuai dengan kemampuan ekonominya. Tetapi tidak menutup kemungkinan bagi masyarakat yang berpenghasilan menengah sampai berpenghasilan tinggi menggunakan motor untuk keperluan sehari-harinya, agar terhindar dari kemacetan lalu lintas kendaraan.

Perkembangan sepeda motor di Indonesia mulai tahun 2011-2015 cenderung mengalami peningkatkan yang signifikan, hal ini ditandai semakin banyaknya iklan sepeda motor yang menawarkan inovasi terbaru yang dilakukan oleh industri sepeda motor guna menarik minat pelanggan yang lebih banyak.

Tabel 1

Perkembangan Jumlah Kendaraan Bermotor Tahun 2010-2015

\begin{tabular}{|c|c|c|}
\hline Tahun & $\begin{array}{c}\text { Jumlah } \\
\text { Spd. Motor }\end{array}$ & $\begin{array}{c}\text { Persentase } \\
(\mathbf{\%})\end{array}$ \\
\hline 2011 & 68.839 .341 & 16,39 \\
\hline 2012 & 76.381 .183 & 18,19 \\
\hline 2013 & 84.732 .652 & 20,18 \\
\hline 2014 & 93.353 .511 & 22,23 \\
\hline 2015 & 96.636 .661 & 23,01 \\
\hline Jumlah & $\mathbf{4 1 9 . 9 4 3 . 3 4 8}$ & $\mathbf{1 0 0}$ \\
\hline
\end{tabular}

Sumber : Badan Pusat Statistik Pusat, Tahun 2015

Data dari Tabel 1.1 tersebut menunjukkan bahwa dengan peningkatan kendaraan sepeda motor setiap tahunnya memberikan gambaran jelas bahwa bisnis sepeda motor merupakan peluang besar bagi para investor untuk dapat memenuhi kebutuhan pelanggan sekaligus memenangkan persaingan, perusahaan harus mempersiapkan strategi pemasaran yang tepat untuk produknya.

\section{Uraian Teori}

\section{Customer Value (Nilai Pelanggan)}

Sekarang ini pelanggan lebih terdidik dan terinformasi dari pada dan mereka memiliki alat untuk menguji klaim-klaim perusahaan dan mencari alternatif-alternatif unggul. Pelanggan mengestimasi tawaran mana yang akan menyerahkan nilai yang paling dirasakan dan bertindak berdasarkan estimasi tersebut. Pelanggan membentuk suatu harapan terhadap nilai dan bertindak berdasarkan hal itu, dan mereka memperhitungkan atau mengevaluasi 
penawaran mana yang akan memberikan nilai tertinggi. Penawaran yang memenuhi harapan nilai pelanggan mempengaruhi kepuasan dan kemungkinan pelanggan membeli kembali.

\section{Persepsi Kualitas}

Persepsi terhadap kualitas dapat didefinisikan sebagai persepsi pelanggan terhadap keseluruhan kualitas atau keunggulan dari suatu produk atau jasa layanan yang berkaitan dengan apa yang diharapkan oleh pelanggan. Sedangkan menurut Durianto, et al (2004) dalam kutipan Sasongko dan Khasanah (2012) bahwa persepsi kualitas pelanggan terhadap produk dan atau atribut yang dimiliki produk (kepentingan tiap pelanggan berbeda).

Persepsi kualitas meliputi segala sesuatu yang berkaitan dengan bagaimana suatu merek dipersepsikan sehingga dengan diketahuinya persepsi pelanggan terhadap kualitas dari merek yang dimiliki maka perusahaan dapat menentukan langkah-langkah apa yang diambil guna memperkuat persepsi pelanggan terhadap merek yang dimiliki oleh perusahaan tersebut.

\section{Kepercayaan}

Menurut Morgan dan Hunt (dalam Suhardi, 2006) mendefinisikan kepercayaan sebagai suatu kondisi ketika salah satu pihak yang terlibat dalam proses pertukaran yakun dengan keandalan dan integritas pihak yang lain. Definisi tersebut menjelaskan bahwa kepercayaan adalah kesediaan atau kerelaan untuk bersandar pada rekan yang terlibat dalam pertukaran yang diyakini. Kerelaan merupakan hasil dari sebuah keyakinan bahwa pihak yang terlibat dalam pertukaran akan memberikan kualitas yang konsisten, kejujuran, bertanggungjawab, ringan tangan dan berhati baik. Keyakinan ini akan menciptakan sebuah hubungan yang dekat antar pihak yang terlibat pertukaran.

\section{Retensi Pelanggan}

Retensi pelanggan adalah
bagaimana mempertahankan hubungan bisnis yang terjadi antara penyedia produk/layanan dengan pelanggan. Retensi pelanggan menekankan kegiatan pemasar dalam mempertahankan pelanggan, menurut Schiffman dan Kanuk (2010) retensi pelanggan didefinisikan sebagai kecenderungan pelanggan di masa depan untuk tetap bertahan terhadap penyedia layanan. Manfaat langsung dari retaining customer atau mempertahankan pelanggan adalah pengurangan biaya pemasaran dan iklan, beberapa penelitian juga menunjukkan pelanggan yang puas dengan sebuah layanan akan melakukan word of-mouth communication.

Pentingnya

kepercayaan

pelanggan, beralih hambatan dan kepuasan pelanggan dalam perencanaan bisnis strategis mereka dalam rangka untuk meningkatkan tingkat retensi pelanggan. Tanpa tujuan yang jelas, setiap misi untuk mengembangkan jumlah konsumen tidak akan banyak bermanfaat bagi perusahaan. Perusahaan harus memiliki target untuk menjaga konsumen yang sudah ada sekaligus menjaring pelanggan baru yang berpotensi mendatangkan profit atau memiliki nilai penting untuk mencapai strategi lainnya. Meskipun demikian tidak semua pelanggan menguntungkan bagi perusahaan, oleh karena itu banyak pelanggan yang tidak perlu dipertahankan, seperti halnya pelanggan yang terlalu memboroskan biaya pelayanan, suka menunggak atau menunda pembayaran tagihan, atau 
konsumen tipe kutu loncat yang suka berpindah-pindah provider.

\section{Kerangka Konseptual}

Perusahaan harus memiliki target untuk menjaga konsumen yang sudah ada sekaligus menjaring pelanggan baru yang berpotensi mendatangkan profit atau memiliki nilai penting untuk mencapai strategi lainnya. Menurut Esti, Lubis, Wijayanto (2013) dan Yunitasari dan Yuniawan (2006) bahwa retensi pelanggan yang dilakukan perusahaan dapat dipengaruhi oleh berbagai variabel independen seperti customer value, persepsi kualitas dan kepercayaan. Untuk mempermudah alur penelitian ini, penulis menggambarkan dalam kerangka konseptual sebagai berikut :

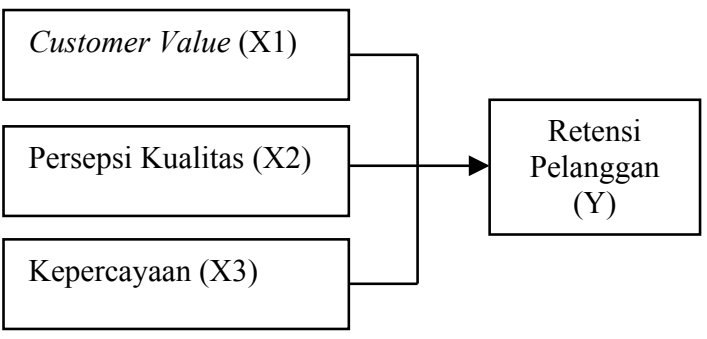

Sumber : Esti, Lubis, Wijayanto (2013) dan Yunitasari dan Yuniawan (2006) Data Diolah, (2016).

\section{Gambar 1 Kerangka Konseptual}

\section{METODE PENELITIAN}

\section{Populasi}

Populasi adalah jumlah dari semua objek atau individu yang akan diteliti, dimana objek tersebut memiliki karakteristik tertentu, jelas dan lengkap (Sugiyono, 2013). Jumlah pelanggan yang terdaftar pada CV Indah Sakti Rantauprapat yang datang untuk service sepeda motor selama tahun 2015 berjumlah 3251 orang.

\section{Sampel}

Sampel adalah bagian dari jumlah dan karakteristik yang dimiliki oleh populasi tersebut (Sugiyono, 2013). Sampel adalah bagian dari populasi yang karakteristiknya hendak diselidiki dan dianggap bisa mewakili keseluruhan populasi. Dalam pengambilan sampel mínimum menggunakan rumus Yamane dalam Akhdon (2011) sebagai berikut :

$$
n=\frac{N}{N \cdot d^{2}+1}
$$

Keterangan :

n : Jumlah sampel

$\mathrm{N} \quad$ : Jumlah populasi

$\mathrm{d}^{2} \quad$ : Presisi (ditetapkan 10\% dengan tingkat kepercayaan 90\%).

$$
\begin{aligned}
& n=\frac{3251}{(3251) \cdot(0,10)^{2}+1}, n=\frac{3251}{33,51} \\
& \quad n=97 \text { orang. }
\end{aligned}
$$

Berdasarkan perhitungan rumus di atas, maka diperoleh jumlah sampel mínimum penelitian sebanyak 97 orang. Teknik pengambilan sampel pada penelitian ini dengan sampel aksidental yaitu teknik pengambilan sampel terhadap siapa saja yang kebetulan bertemu dengan peneliti dilokasi penelitian.

\section{Jenis dan Sumber Data}

Jenis data pada penelitian ini menggunakan data kuantitatif yaitu data yang berbentuk angka atau bilangan yang dapat diolah atau dianalisis dengan mengggunakan teknik perhitungan matematika atau statistika. Sedangkan sumber data yang digunakan adalah sebagai berikut :

1. Data primer yaitu pengumpulan data yang diperoleh melalui 
observasi, wawancara dan kuesioner yang berisi pernyataanpernyataan variabel penelitian.

2. Data sekunder yaitu data yang diperoleh melalui hasil pengolahan data pihak kedua dan hasil penelitian lapangan antara lain diperoleh dari studi pustaka.

\section{HASIL DAN PEMBAHASAN}

\section{Pembahasan}

Hasil analisis secara keseluruhan dapat membuktikan bahwa :

1. Hipotesis pertama yang diajukan dalam penelitian terbukti diterima, yang menyatakan bahwa variabel customer value memiliki pengaruh paling dominan terhadap retensi pelanggan. Nilai pelanggan adalah selisih nilai pelanggan total dan biaya pelanggan total dimana nilai pelanggan total adalah sekumpulan manfaat yang diharapkan oleh pelanggan dari produk atau jasa tertentu dan biaya pelanggan total adalah sekumpulan biaya yang diharapkan oleh pelanggan yang dikeluarkan untuk mengevaluasi, mendapatkan, menggunakan dan membuang produk atau jasa. Nilai pelanggan atau customer value yaitu persepsi pelanggan terhadap nilai dimana perusahaan harus mempertimbangkan nilai dalam mengembangkan produk dan jasanya sehingga sesuai dengan apa yang diharapkan pelanggan. Dimana keuntungan yang dirasakan adalah kombinasi dari atribut fisik, atribut jasa dan teknik pendukung dalam pemanfaatan produk. Pengorbanan yang dikeluarkan adalah total biaya yang dikeluarkan pelanggan termasuk biaya pembelian dan biaya tambahan (seperti biaya pemesanan, transportasi, instalasi, penanganan pesanan) serta biaya diluar pembelian (mengganti kerusakan, resiko kegagalan atau pelayanan yang buruk). Nilai pelanggan adalah persepsi pelanggan terhadap nilai atas kualitas yang ditawarkan relatif lebih tinggi dari pesaing akan mempengaruhi tingkat loyalitas pelanggan, semakin tinggi persepsi nilai yang dirasakan oleh pelanggan, maka semakin besar kemungkinan terjadinya hubungan (transaksi). Dan hubungan yang diinginkan adalah hubungan yang bersifat jangka panjang, sebab usaha dan biaya yang dikeluarkan oleh perusahaan diyakini akan jauh lebih besar apabila harus menarik pelanggan baru atau pelanggan yang sudah meninggalkan perusahaan, daripada mempertahankannya.

2. Hipotesis kedua yang diajukan dalam penelitian ini terbukti ditolak, yang menyatakan bahwa variabel persepsi kualitas tidak memiliki pengaruh terhadap retensi pelanggan. Peperangan antara produsen untuk merebutkan persepsi pelanggan. Demikian pentingnya persepsi di benak pelanggan, sehingga bermacammacam strategi di rancang perusahaan supaya produk dan mereknya bisa menjadi no satu di benak pelanggan. Dengan demikian persepsi kualitas yang menjadi cara pandang pelanggan merupakan perilaku yang terbentuk terhadap barang atau jasa sebagai pembelian produk tersebut. Persepsi kualitas ini sangat penting karena akan berdampak pada kelancaran bisnis atau perusahaan. Pelanggan yang merasa puas akan jasa/produk yang digunakannya akan kembali menggunakan jasa/produk yang ditawarkan. Hal ini akan membangun 
kesetiaan pelanggan. Persepsi pelanggan sendiri diartikan sebagai suatu keadaan dimana harapan pelanggan terhadap suatu produk sesuai dengan kenyataan yang diterima oleh pelanggan tersebut tentang kemampuan produk tersebut. Jika produk tersebut jauh dibawah harapan pelanggan maka ia akan kecewa. Sebaliknya jika produk tersebut memenuhi harapan pelanggan, maka ia akan senang. Harapan-harapan pelanggan ini dapat diketahui dari pengalaman mereka sendiri saat menggunakan produk tersebut, omongan-omongan orang lain, dan informasi iklan yang dijanjikan oleh perusahaan yang menghasilkan produk tadi.

3. Hipotesis ketiga yang diajukan dalam penelitian ini terbukti diterima, yang menyatakan bahwa variabel kepercayaan memiliki pengaruh terhadap retensi pelanggan. Kepercayaan pelanggan adalah semua pengetahuan yang dimiliki pelanggan dan semua kesimpulan yang dibuat pelanggan tentang objek, atribut dan manfaatnya. Dalam konsep relationship marketing, kepercayaan merupakan salah satu dimensi dari relationship marketing untuk menentukan sejauhmana yang dirasakan suatu pihak mengenai integritas dan janji yang ditawarkan pihak lain. Kepercayaan terhadap merek terbentuk dari pengalaman masa lalu dan interaksi sebelumnya. Suatu pengalaman konsumsi dapat didefinisikan sebagai kesadaran dan perasaan yang dialami pelanggan selama pemakaian produk atau jasa. Kepercayaan adalah keyakinan bahwa seseorang akan menemukan apa yang diinginkan pada mitra pertukaran.
Kepercayaan melibatkan kesediaan seseorang untuk bertingkah laku tertentu karena keyakinan bahwa mitranya akan memberikan apa yang ia harapkan dan suatu harapan yang umumnya dimiliki seseorang bahwa kata, janji atau pernyataan orang lain dapat dipercaya. Pengukuran kepercayaan adalah kinerja perusahaan secara keseluruhan memenuhi harapan, pelayanan yang diberikan perusahaan secara konsisten terjaga kualitasnya, percaya bahwa perusahaan tersebut akan bertahan lama. Dari definisi diatas, kepercayaan dapat diartikan sebagai suatu perasaan untuk yakin terhadap pihak lain maupun terhadap suatu hubungan.

4. Hipotesis keempat yang diajukan dalam penelitian ini terbukti diterima, yang menyatakan bahwa variabel customer value, persepsi kualitas dan kepercayaan secara bersama-sama memiliki pengaruh terhadap retensi pelanggan. Berdasarkan hasil analisis tersebut maka terdapat keterkaitan antara retensi pelanggan yang meliputi customer value, persepsi kualitas dan kepercayaan. Dengan demikian dapat disimpulkan bahwa dengan semakin baik customer value, persepsi kualitas dan kepercayaan perusahaan maka secara langsung mempengaruhi retensi pelanggan.

\section{KESIMPULAN}

Berdasarkan hasil penelitian dan interprestasi pembahasan yang dilakukan, maka diperoleh kesimpulan pada penelitian ini sebagai berikut :

1. Hipotesis pertama yang diajukan dalam penelitian terbukti diterima, yang menyatakan bahwa variabel customer value memiliki 
pengaruh paling dominan terhadap retensi pelanggan.

2. Hipotesis kedua yang diajukan dalam penelitian ini terbukti ditolak, yang menyatakan bahwa variabel persepsi kualitas tidak memiliki pengaruh terhadap retensi pelanggan.

3. Hipotesis ketiga yang diajukan dalam penelitian ini terbukti diterima, yang menyatakan bahwa variabel kepercayaan memiliki pengaruh terhadap retensi pelanggan.

4. Hipotesis keempat yang diajukan dalam penelitian ini terbukti diterima, yang menyatakan bahwa variabel customer value, persepsi kualitas dan kepercayaan secara bersama-sama memiliki pengaruh terhadap retensi pelanggan.

\section{DAFTAR PUSTAKA}

Akhdon. 2011. Cara Menggunakan dan Memaknai Path Analysis (Analisis Jalur). Bandung : Alfabeta.

Buttle, Francis. 2009. Customer Relationship Management (Manajemen Hubungan Pelanggan): Concept and Tools. Malang. Bayumedia Publishing.

Diab, Balqis. 2009. Analisis Pengaruh Nilai Elanggan Dan Citra Merek Terhadap Kepuasan Pelanggan Dalam Meningkatkan Retensi Pelanggan (Studi Kasus pada Gies Batik Pekalongan). Tesis Program Studi Magister Manajemen Program Pasca Sarjana Universitas Diponegoro.

Hoffman, K dan Basteson, Jhon E.G. 2006.Service Marketing : Concepts, Strategies dan Cases. Third Edition. USA. Thomson South-Western
Kotler, Philip. 2007. Prinsip-prinsip Pemasaran I Edisi Keduabelas, Gramedia Pustaka, Jakarta.

Kotler, Philip dan Keller, Kevin. L. 2008. Manajemen Pemasaran Jilid 1. Edisi 12.Alih Bahasa Benyamin Molan.Jakarta : Indeks

Kristanto, A. 2005. Analisis Pengaruh Asosiasi Merek, Nilai Produk, dan Kualitas Pelayanan Terhadap Kepuasan, Serta Hubungannya Dengan Retensi Konsumen: Studi Mengenai Motor Merek Honda di Jakarta. Tesis. Jakarta: Program Studi Magister Manajemen UI.

Sasongko dan Khasanah. 2012. Analisis Pengaruh Motivasi Konsumen, Persepsi Kualitas dan Sikap Konsumen Terhadap Keputusan Pembelian PC Tablet iPad (Studi pada Konsumen iPad di Semarang). CBAM Fakultas Ekonomi UNISSULA Vol. I No. I Desember 2012.

Schiffman, Leon G. dan Kanuk, Leslie Lazar. 2010. Consumer Behavior. 10th edition, New Jersey: Pearson Prentice Hall

Sugiyono. 2013. Metode Penelitian Bisnis, Alfabeta, Bandung.

Suhardi, Gunarto. 2006. Faktor-Faktor yang Mempengaruhi Kepercayaan dan Loyalitas Nasabah Perbankan Di Surabaya. Jurnal KINERJA. (Vol. 10 No.1).

Win Esti, Nawazirul Lubis, Andi Wijayanto. 2013. Pengaruh Nilai Pelanggan Terhadap Retensi Pelanggan Melalui Kepuasan (Studi Pada Mahasiswa Jurusan Administrasi Bisnis Universitas Diponegoro Angkatan 20092012 Pengguna Layanan Data Smartfren). Diponegoro Journal 
Of Social And Politic Tahun 2013, Hal. 1-10.

Yunitasari dan Yuniawan. 2006. Analisis Pengaruh Kesadaran Merek, Persepsi Kualitas Dan Loyalitas Merek Terhadap Nilai Pelanggan Mobil Merek Toyota. Jurnal Studi Manajemen \& Organisasi Volume 3, Nomor 2, Juli, Tahun 2006, Halaman 15 